Short Communication

\title{
Performance of Stainless Steel AISI 317L in Hydrochloric Acid with the Addition of Propargyl Alcohol
}

\author{
Fernando B. Mainier ${ }^{1, *}$, Humberto Nogueira Farneze ${ }^{2}$, Laís Ferreira Serrão ${ }^{l}$, \\ Bárbara Tannus de Oliveira ${ }^{1}$, Bruna F. Nani ${ }^{1}$ \\ ${ }^{1}$ Escola de Engenharia, Universidade Federal Fluminense, Niterói, RJ, Brazil. \\ ${ }^{2}$ Centro Federal de Educação Tecnológica Celso Suckow da Fonseca de Itaguaí; Itaguaí, RJ, Brazil. \\ *E-mail: $\underline{\text { fmainier@uol.com.br }}$
}

doi: $10.20964 / 2018.04 .02$

Received: 17 November 2017 / Accepted: 23 January 2018 / Published: 6 March 2018

\begin{abstract}
AISI 317L stainless steel is a material that is used in many industries, including the manufacturing of equipment and components applied in the oil \& gas industry, which are subject to acidification or acid stimulation. Acid stimulation consists, essentially, of hydrochloric acid injection of 5 to $28 \%$ (\% volume) in oil and gas wells to stimulate or restore the permeability of the reservoir rock, which increases the production of oil and gas. To avoid or to reduce the attack of hydrochloric acid on stainless steel AISI 317L, the corrosion inhibitor, propargyl alcohol base, is added. Thus, the present paper aims to analyze AISI 317L stainless steel's corrosion resistance using gravimetric (mass loss) and electrochemical (polarization) laboratory tests with and without the addition of $1 \%$ (volume) propargyl alcohol in hydrochloric acid solutions at concentrations of 5 and $10 \%$ (\% volume) at temperatures of $25^{\circ} \mathrm{C}, 40^{\circ} \mathrm{C}$ and $55^{\circ} \mathrm{C}$. The laboratory results are very promising in protecting the AISI 317L stainless steel in hydrochloric acid solutions.
\end{abstract}

Keywords: AISI 317L, Corrosion, Corrosion Inhibitors, Propargyl Alcohol, Hydrochloric acid.

\section{FULL TEXT}

(C) 2018 The Authors. Published by ESG (www.electrochemsci.org). This article is an open access article distributed under the terms and conditions of the Creative Commons Attribution license (http://creativecommons.org/licenses/by/4.0/). 